Proceeding of the $2^{\text {nd }}$ International Conference on Agriculture, Food Security and Safety, Vol. 2, 2021, pp. 29-43 Copyright C 2021 iConferences

ISSN 2682-7158

DOI: https://doi.org/10.32789/agrofood.2021.1003

\title{
Ensiled Fruit Peels of Pineapple (Ananas comosus) and Papaya (Carica papaya) as an Animal Feed
}

\author{
Wimalasiri $\mathrm{S}^{1}$ and Somasiri S.C ${ }^{2 *}$ \\ ${ }^{1}$ Department of Animal and Food Sciences, Faculty of Agriculture, Rajarata University of \\ Sri Lanka, Anuradhapura, Sri Lanka, sumudu.senaniw@gmail.com \\ ${ }^{2}$ Department of Animal and Food Sciences, Faculty of Agriculture, Rajarata University of \\ SriLanka, Anuradhapura, SriLanka,sharinisc@agri.rjt.ac.lk
}




\title{
ENSILED FRUIT PEELS OF PINEAPPLE (Ananas comosus) AND PAPAYA (Carica papaya) AS AN ANIMAL FEED
}

\begin{abstract}
One of the major issues for the development of the livestock sector in Sri Lanka is the unavailability of quality animal feeds. Thus, this study was carried out to prepare value-added silages using fruit peels for feeding livestock. Silage has been prepared using pineapple (Ananas comosus) and papaya (Carica papaya) fruit peels obtained from a fruit processing factory in Sri Lanka. Ensiling was done either in fruit peels only or in different combinations of fruit peels and chopped Hybrid Napier (CO-3 Pennisetum perpureum $\times$ Pennisetum americarnum) grass. The experimental design was a completely Randomized Design having ten treatments (T1 to T10) with two replicates per each. The treatments were T1 Papaya 100\%, T2 Pineapple 100\%, T3 Grass $100 \%$, T4 Pineapple $75 \%+$ Papaya 25\%, T5 Pineapple 50\%+ Papaya 50\%, T6 Pineapple 25\%+ Papaya $75 \%$, T7 Pineapple $20 \%+$ Papaya $70 \%+$ Grass $10 \%$, T8 Pineapple $30 \%+$ Papaya $50 \%+$ Grass $20 \%$, T9 Pineapple $70 \%+$ Papaya $20 \%+$ Grass $10 \%$, and T10 Pineapple $50 \%+$ Papaya $30 \%+$ Grass $20 \%$. The fruit peels and grass were dried under shade, chopped, and mixed according to the different treatments. After 21days, representative silage samples from each treatment were analyzed for nutrient content, colour, odour, $\mathrm{pH}$, and Ammonium Nitrogen $\left(\mathrm{NH}_{3} \mathrm{~N}\right)$ content. The colour of all silages ranged from olive green to orange. All the treatments had a fruity smell. The $\mathrm{pH}$ values ranged from 3.41 to 4.04 in all treatments. The highest $(p<0.05)$ crude protein $(\mathrm{CP})$ content was in T3, and the lowest $(p<0.05)$ was observed in T4 and T5. The highest $(p<0.05)$ acid detergent fibre (ADF) contents were in T3, T8, and T10, and the lowest $(p<0.05)$ was in $\mathrm{T} 5$ and T6. The highest $(p<0.05)$ neutral detergent fibre (NDF) content was in T9 $(44.00 \pm 0.02 \%)$ and the lowest $(p<0.05)$ in T2. The $\mathrm{NH}_{3} \mathrm{~N}$ was not present in any of the treatments. Based on $\mathrm{CP}, \mathrm{ADF}$, and NDF contents, $\mathrm{T} 1$, $\mathrm{T} 7, \mathrm{~T} 8, \mathrm{~T} 9$, and $\mathrm{T} 10$ were selected for further studies with animals to select the best treatment.
\end{abstract}

Keywords: Ammonium Nitrogen $\left(\mathrm{NH}_{3} \mathrm{~N}\right)$, ensiled fruit peels, nutrient content, physical characteristics

\section{Introduction}

Earlier livestock rearing in Sri Lanka was a rural live-hood activity that utilized idling labour, underutilized agricultural by-products, and marginal lands. However, presently, livestock is one of the fastest-growing agricultural subsector in Sri Lanka (Weerasinghe, 2019). The growth of the livestock sector during 2017 was $3.9 \%$, along with a $0.6 \%$ contribution to the Gross Domestic Production (GDP) of Sri Lanka (Livestock Statistical Bulletin, 2017). The consumption of livestock products has increased drastically over the last two decades with the increase of per capita income, urbanization, and changes in socio-cultural status (Weerasinghe, 2019). Thus, the optimum performance of the livestock has become very important, increasing the demand for quality animal feeds (Wickramasuriya et al., 2015). With the expansion of the livestock sector, depending only on locally available feed ingredients was not sufficient to meet the feeding requirements of different livestock species. Therefore, the principal technical constraint in livestock production in developing countries 


\section{Somasiri S.C. / Ensiled fruit peels of pineapple (Ananas comosus) and papaya (Carica papaya) as an animal feed}

like Sri Lanka has always been a lack of quality feed resources and nutrition (Devendra and Sevilla, 2002). Either the lack of quality feeds, or the unaffordability of available quality feeds by farmers greatly affects livestock production in Sri Lanka as most of the farmers are either small-scale or medium-scale (Wadhwa et al., 2013). The increasing human population pressurizes the livestock sector badly. The grazing animals have limited land for grazing, and fodder cultivation is also limited by inadequate land (Devendra, 1999). The combined effects of climate change, land degradation, cropland losses, water scarcity, and the high cost of inputs such as fertilizer and pesticides have increased the cost of feed ingredients such as cereals (Wadhwa et al., 2015). Even if feed ingredients are imported, there will not be a guarantee for cheap and higher quality. Hence, the attention has been focused on using alternative feed resources that would be available at relatively low cost with appreciable levels of essential nutrients (Kasapidou et al., 2015).

In addition, the ongoing shift in cropping patterns from cereals to more economical fruit and vegetable crops in Sri Lanka has also decreased the availability and supply of cereals and crop residues for animal feeding (Weerasinghe, 2019). Due to this reason, developing countries, including Sri Lanka, produce huge quantities of fruits that are around 540,000 metric tons annually (Sri Lanka Export Development Board, 2013). These are usually consumed either fresh or processed and sometimes as value-added products. The fruit industry in Sri Lanka comprises processors of fruits and exporters of fresh and processed fruit (Sri Lanka Export Development Board, 2013). A significant amount of the harvest is wasted at the processing site. When the fruit beverage industry is considered, lots of fruit wastes are dumped after processing without any other further utilization, especially the peels of different types of fruits (Rani and Nand, 2004). This dumping of a large amount of fruit harvest as waste has caused a major reason for environmental pollution in areas where such factories are established. The waste is dumped in waterways or soiled or just left on a passage of a nearby land. This causes huge environmental issues (Rani and Nand, 2004).

Environmental pollution due to the effect of perishing fruit wastes needs immediate attention. Because it is costly and affects the profits of the fruit processing factories, ensiling or drying of fruit peels has been undertaken by countries like India, China, etc. (Wadhwa et al., 2013). Therefore, as a solution to the fruit wastes available in the fruit processing factories, ensiling can be proposed. The fruit peels such as pineapple, and papaya waste, which are produced daily at the factories in large quantities in Sri Lanka, need to be processed immediately. Thus, this study was focused on the preparation of silage using the above fruit peels to be used as a value-added feed for livestock.

\section{Materials and Methodology}

\section{Experiment Location}

Preparation of silage and the laboratory analysis were conducted at the Animal Science Laboratory, Faculty of Agriculture, Rajarata University of Sri Lanka, Puliyankulama, Anuradhapura, Sri Lanka. 


\section{Raw Materials}

Fruit peels were collected from the processing site of Lanka Canneries Pvt Ltd, Aththanagalla, Sri Lanka, and other locally available fruit processing centres in Anuradhapura, Sri Lanka. Silos were prepared using 500-gauge black colour polythene purchased from the local market. The size of the silos was $45 \mathrm{~cm}$ in length $\times 30 \mathrm{~cm}$ in width, respectively.

\section{Experimental design}

There were 10 treatments (Table 1), and each treatment had two replicates. The experimental design was a completely randomized design (CRD).

\section{Process of silage making}

Peels of fresh fruits which were collected from Lanka Canneries Pvt Ltd were stored in a deep freezer, and the frozen peels were transported to the site at the faculty in closed containers to avoid fermentation and other contaminations. The other peels obtained locally were kept under refrigerated conditions until the silage preparation. On the day of silage preparation, the fruit peels were sun-dried up to $80 \%$ moisture. The sun-dried fruit peels were then chopped. This was done manually using sharp knives while avoiding contaminations. The chopped fruit peels were mixed according to the different combinations (Treatments) shown in Table 1 and filled into silos tightly so that the chopped peels would be stacked well. Immediately after filling, the silos were sealed airtightly to ensure no air was trapped inside the silos, which would favour aerobic fermentation. The silos were placed at room temperature for 21 days in a dark place without any disturbances. The physical damages like insect and rodents' attacks were prevented. The silos were not opened until 21 days.

Table 1: Different fruit peel combinations (Treatments) used in the silage preparation

\begin{tabular}{l|l} 
Treatment number & Different combinations of fruit peels \\
\hline 1 & Pineapple $100 \%$ \\
2 & Papaya $100 \%$ \\
\hline 3 & Grass $100 \%$ \\
4 & Pineapple $75 \%$, Papaya $25 \%$ \\
\hline 5 & Pineapple $50 \%$, Papaya $50 \%$ \\
6 & Pineapple $25 \%$, Papaya $75 \%$ \\
\hline 7 & Pineapple $20 \%$, Papaya $70 \%$, Grass $10 \%$ \\
8 & Pineapple $30 \%$, Papaya $50 \%$, Grass $20 \%$ \\
\hline 9 & Pineapple $70 \%$, Papaya $20 \%$, Grass $10 \%$ \\
10 & Pineapple $50 \%$, Papaya $30 \%$, Grass $20 \%$
\end{tabular}

Note: Grass (Hybrid Napier CO-3 (Pennisetum perpureum $\times$ Pennisetum americarnum) was obtained from the Faculty of Agriculture farm and dried up to $65 \%$ moisture level and chopped before include in the respective treatments. 
Somasiri S.C. / Ensiled fruit peels of pineapple (Ananas comosus) and papaya (Carica papaya) as an animal feed

\section{Physical Analysis of Silage Samples}

The silos were opened after 21days and tested for physical characteristics such as silage colour, texture, aroma, and presence of worms and moulds with reference to Fernando and Nanthakumaran (2018).

\section{Proximate composition of different treatments}

Silage samples obtained from each replicate were oven-dried at $55^{\circ} \mathrm{C}$ for 6 hours. The oven-dried samples were ground and sieved using a $1 \mathrm{~mm}$ sieve and used for proximate analysis (AOAC, 2005) to determine dry matter (DM), crude protein (CP), crude fibre (CF), ether extract (EE), and ash.

Dry matter (DM) content was determined by oven drying fresh samples at $105^{\circ} \mathrm{C}$ until constant weight using a hot air oven (YCO-010, Taiwan). Nitrogen content was determined using the Kjeldahl method (DK 20, Italy), and using the equation of $\mathrm{N} \times 6.25$, crude protein content was calculated. Ether extract content was determined using the Soxhlet Extractor method (MICROSIL, India). Crude fibre content was determined according to the procedures given at AOAC, 2005, using fibre extractor (FIWE3, Italy), Soxhlet Extractor (MICROSIL, India), and muffle furnace (DMF-05, Korea). Ash content was determined by burning the samples in a muffle furnace (DMF- 05 , Korea)) at $600^{\circ} \mathrm{C}$ for about 4 hours.

Acid Detergent Fibre (ADF) and Nutrient Detergent Fibre (NDF) were determined using the Van Soest Analysis procedure (Randa et al., 2017), using the fibre extractor (FIWE3, Italy). Nitrogen-free extract (NFE), in-vitro Total digestible nutrients (TDN), and Metabolizable Energy (ME) content were calculated using the following equations.

NFE \%=100-(Ash \%-CP \%-CF \%-EE \%) (Source: Ibrahim, 1988)

Invitro TDN $=-112.8+2.341(\mathrm{CP})+1.799(\mathrm{NFE})+2.885(\mathrm{EE})+1.900(\mathrm{CF})$

(Source: Fonnesbeck et al., 1984)

$\mathrm{ME}=\mathrm{TDN} \times 0.03615$ (Source: Ibrahim, 1988)

\section{Determination of ammonium nitrogen concentration}

Representative silage samples of 20 grams were taken from each replicate. The sample was ground with $100 \mathrm{ml}$ of distilled water using a laboratory grinder. Then a fraction of suspension was filtered through a filter paper to obtain a filtrate of $5 \mathrm{ml}$. The $\mathrm{pH}$ of that filtrate was immediately measured using a compact $\mathrm{pH}$ meter. The other fraction of the suspension was put into $1000 \mathrm{ml}$ of sealed plastic bottles and left overnight at $4^{\circ} \mathrm{C}$ for extraction of juice. The extract was filtered using a filter paper, and the filtrate was used for the determination of ammonium nitrogen concentration using the phenolnitroprusside spectrophotometric method (Markus et al., 1985).

\section{Data Analysis}

The experiment was conducted in a completely randomized design (CRD) with ten treatments and two replicates per treatment. Nutrient content was analyzed using the one-way Analysis of Variance (ANOVA) procedure in Statistical Analysis Software, version 9.0 (SAS, 2002). Mean separation was done using the Least Significant Difference (LSD) method. Statistical significance was declared at $p<0.05$. 
Somasiri S.C. / Ensiled fruit peels of pineapple (Ananas comosus) and papaya (Carica papaya) as an animal feed

\section{Results and Discussion}

\section{Determination of Physical Characteristics of Silage}

The physical characteristic (texture, colour, and odour) were determined according to standards stated by Fernando et al., 2018, for the sample silages produced using individual fruit peels (pineapple \& papaya) and different combinations of fruit peels + fodder and presented in Table 2 . The absence of moulds and worms in the silage indicated that proper fermentation took place in the silage.

Table 2: The sensory analysis of texture, colour, and odour of silage made from individual fruit peels and fodder and the different combinations of fruit peels and fodder

\begin{tabular}{|c|c|c|c|c|}
\hline $\begin{array}{l}\text { Treatment } \\
\text { No. }\end{array}$ & $\begin{array}{l}\text { Combinations of fruit } \\
\text { peels and fodder } \\
\text { used to make silage }\end{array}$ & Texture & Colour & Odour \\
\hline 1 & $100 \%$ Pineapple peel & Soft fibrous & Olive green & Fruity smell \\
\hline 2 & 100\% Papaya peel & Fleshy soft & Light orange & Fruity smell \\
\hline 3 & $\begin{array}{l}\text { 100\% Pennisetum purpureum } \\
\text { (Hybrid Napier (CO-3) }\end{array}$ & Leafy soft & Light green & Sweet arome \\
\hline 4 & $\begin{array}{l}75 \% \text { Pineapple peel }+25 \% \text { Papaya } \\
\text { peel }\end{array}$ & $\begin{array}{l}\text { Soft, fleshy, } \\
\text { fibrous }\end{array}$ & $\begin{array}{l}\text { Light orange mixed } \\
\text { olive green }\end{array}$ & Fruity smell \\
\hline 5 & $\begin{array}{l}50 \% \text { Pineapple peel }+50 \% \text { Papaya } \\
\text { peel }\end{array}$ & $\begin{array}{l}\text { Soft, fleshy, } \\
\text { fibrous }\end{array}$ & Brown- orange & Fruity smell \\
\hline 6 & $\begin{array}{l}25 \% \text { Pineapple peel }+75 \% \text { Papaya } \\
\text { peel }\end{array}$ & $\begin{array}{l}\text { Soft, fleshy, } \\
\text { fibrous }\end{array}$ & Bright orange & Fruity smell \\
\hline 7 & $\begin{array}{l}20 \% \text { Pineapple peel }+70 \% \text { Papaya } \\
\text { peel }+10 \% \text { CO-3 }\end{array}$ & $\begin{array}{l}\text { Leafy soft fleshy } \\
\text { fibrous }\end{array}$ & $\begin{array}{l}\text { Olive green mixed } \\
\text { orange }\end{array}$ & Fruity smell \\
\hline 8 & $\begin{array}{l}30 \% \text { Pineapple peel }+50 \% \text { Papaya } \\
\text { peel }+20 \% \text { CO-3 }\end{array}$ & $\begin{array}{l}\text { Leafy soft fleshy } \\
\text { fibrous }\end{array}$ & $\begin{array}{l}\text { Orange mixed olive } \\
\text { green }\end{array}$ & Fruity smell \\
\hline 9 & $\begin{array}{l}70 \% \text { Pineapple peel }+20 \% \text { Papaya } \\
\text { peel }+10 \% \text { CO-3 }\end{array}$ & $\begin{array}{l}\text { Leafy soft fleshy } \\
\text { fibrous }\end{array}$ & $\begin{array}{l}\text { Orange mixed olive } \\
\text { green }\end{array}$ & Fruity smell \\
\hline 10 & $\begin{array}{l}50 \% \text { Pineapple peel }+30 \% \text { Papaya } \\
\text { peel }+20 \% \text { CO-3 }\end{array}$ & $\begin{array}{l}\text { Leafy soft fleshy } \\
\text { fibrous }\end{array}$ & $\begin{array}{l}\text { Orange mixed olive } \\
\text { green }\end{array}$ & Fruity smell \\
\hline
\end{tabular}

\section{Presence of Fungus and Worms in Silage Samples}

Visual observation showed that no moulds and worms were presented in any of the silage samples. It indicated that aerobic fermentation had been prevented and anaerobic fermentation had occurred, and it also showed well compaction during silage making.

\section{Texture of Silage Samples}

When $100 \%$ pineapple peel included silage was considered, the texture was soft and relatively fibrous because fibre in the pineapple peel was high (Table 2). The 100\% papaya peel included silage and was fleshier and softer rather than being fibrous (Table 2). The 100\% CO-3 included silage and was leafy soft (Table 2). The texture of other silages made from including CO-3 in addition to papaya peel and pineapple peel were leafy along with being soft, fleshy, and fibrous (Table 2). 


\section{Odour of Silage Samples}

The odour of all the silages was fruity smell except T3 (100\% CO-3 grass). The T3 had a sweet aroma as it included only grass. Therefore, silage from T3 can be defined as a moderately wilted silage with little fermentation (Kaiser et al., 2004). However, well-fermented silages should not have a particularly strong odour because lactic acid, which is the main organic acid from fermentation, is nearly odourless. But in here, the used peels of ripening pineapple and papaya already have a pleasant odour due to which the odour of silages has become prominent. Most silages tend to have a mild odour of vinegar or acidic (acetic acid) nature. It may be because acetic acid would be the secondhighest concentration after lactic acid, and it is very volatile (Jr et al., 2018).

The effluent of silages was reduced. The effluent in silage refers to the surplus moisture released by low DM silages. It contains valuable nutrients, including water-soluble carbohydrates (WSC), silage fermentation products, and minerals (Aboulfotoh, 2019). The quantity of effluent is directly related to the DM content of the parent material ensiled and the extent of compaction of the silage (Gowda et al., 2015). The effluent flow falls as DM content increases and stops when the DM content reaches $30 \%$ (Aboulfotoh, 2019). The DM content of the peels and CO-3 were brought up to levels given in Table 5 by sun drying. Therefore, the effluent was reduced as parental materials were sun-dried enough, and the silages had been well stacked.

\section{Colour of Silage Samples}

The colour (Plate 1) of 100\% pineapple peel included silage and was olive green as the yellow colour of fresh ripened pineapple peel had been subjected to anaerobic fermentation during ensiling. The colour of $100 \%$ papaya peel included silage was light orange, and there was not a considerable colour change compared to fresh ripen papaya peel. The 100\% CO-3 included silage and was light green in colour as expected. When silage was made from different combinations of pineapple peel and papaya peel, it showed the fermented colour of the peel, which was included in greater proportion. For example, the colour of silage made using $75 \%$ pineapple peel along with $25 \%$ papaya peel was light orange mixed olive green, while the colour of silage made using $75 \%$ papaya peel along with $25 \%$ pineapple peel was bright orange reflecting the fermented colour of fresh ripened papaya peel. The $50 \%$ papaya peel and $50 \%$ pineapple peel included silage had shown brown-orange in colour. The $20 \%$ pineapple peel, $70 \%$ papaya peel, and 10\% CO-3 included silage had an olive-green mixed orange colour. And the rest of the silages (T8, T9, and T10) had an orange mixed olive-green colour. Therefore, the colours of all the silages were attractive. 
Somasiri S.C. I Ensiled fruit peels of pineapple (Ananas comosus) and papaya (Carica papaya) as an animal feed

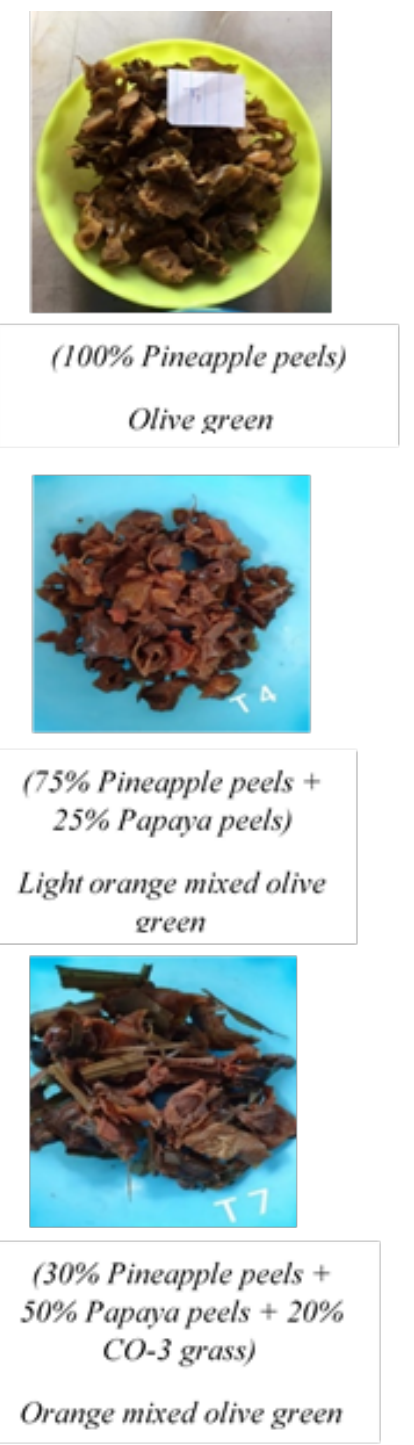

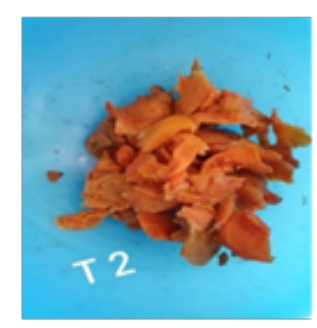

(100\% Papaya peels)

Light orange

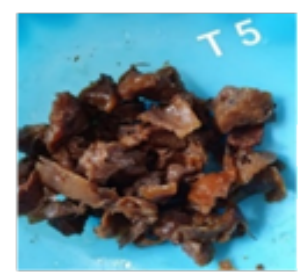

(50\% Pineapple peels + $50 \%$ Papaya peels)

Brown orange

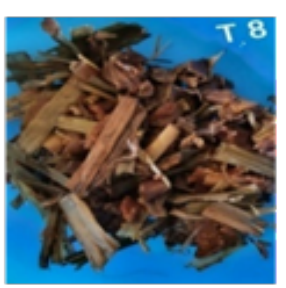

(20\% Pineapple peels $+70 \%$

Papaya peels $+10 \% \mathrm{CO}-3$ grass)

Olive sreen mixed oranse

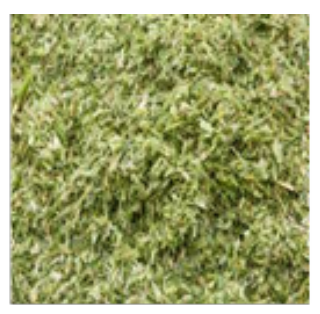

(100\% CO-3 grass)

Light green

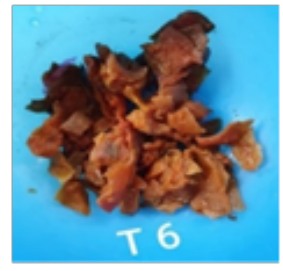

(25\% Pineapple peels + 75\% Papaya peels)

Bright oranoe

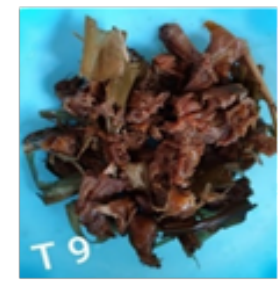

$50 \%$ Pineapple peels + $30 \%$ Papaya peels $+20 \%$ $\mathrm{CO}-3$ grass

Orange mixed olive green

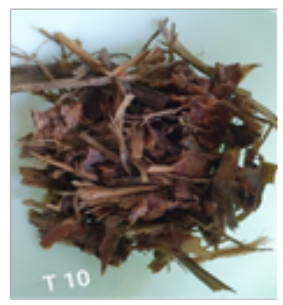

(50\% Pineapple peels $+30 \%$

Papaya peels $+20 \% \mathrm{CO}-3$

grass)

Orange mixed olive green

Figure 1: Plate 1 Colour of Silages 
Somasiri S.C. / Ensiled fruit peels of pineapple (Ananas comosus) and papaya (Carica papaya) as an animal feed

pH Value of Silage Samples

Table 3: Quality of silage based on $\mathrm{pH}$ value

\begin{tabular}{c|c} 
pH range & Quality \\
\hline $3.4-3.7$ & Low \\
$3.8-4.2$ & Moderate \\
\hline $4.3-4.6$ & High \\
$>4.6$ & Very high
\end{tabular}

Source: Fernando and Nanthakumaran (2018)

The $\mathrm{pH}$ of different silage samples is given in Table 4. They have been categorized quality-wise based on their $\mathrm{pH}$ values as low quality, moderate quality, high quality, and very high quality with reference to Fernando and Nanthakumaran (2018) (Table 3).

The $\mathrm{pH}$ values of $\mathrm{T} 1, \mathrm{~T} 8, \mathrm{~T} 9$, and $\mathrm{T} 10$ silages belonged to moderate quality, while $\mathrm{T} 2, \mathrm{~T} 4, \mathrm{~T} 5, \mathrm{~T} 6$ and, $\mathrm{T} 7$ belonged to low-quality silage. The main reason for their low $\mathrm{pH}$ values might be the poor fermentation during ensiling, as the ensiling period was only 21 days. The silages, T8, T9, and T10, proved to be of good quality depending on $\mathrm{pH}$ values. Therefore, T1, T8, T9, and T10 treatments are better to make silage.

Table 4: pH of silage made from individual fruit peels and fodder and the different combinations of fruit peels and fodder

\begin{tabular}{l|llc} 
Treatment No. & $\begin{array}{l}\text { Combinations of fruit peels and fodder used to } \\
\text { make silage }\end{array}$ & pH value & Quality \\
\hline $\mathbf{1}$ & $100 \%$ Pineapple peel & $3.81\left(28.8^{\circ} \mathrm{C}\right)$ & Moderate \\
$\mathbf{2}$ & $100 \%$ Papaya peel & $3.75\left(28.3^{\circ} \mathrm{C}\right)$ & Low \\
\hline $\mathbf{3}$ & $100 \% \mathrm{CO} 3$ & $3.72\left(28.2^{\circ} \mathrm{C}\right)$ & Low \\
$\mathbf{4}$ & $75 \%$ Pineapple peel $+25 \%$ Papaya peel & $3.41\left(31.4^{\circ} \mathrm{C}\right)$ & Low \\
\hline $\mathbf{5}$ & $50 \%$ Pineapple peel $+50 \%$ Papaya peel & $3.62\left(30.0^{\circ} \mathrm{C}\right)$ & Low \\
$\mathbf{6}$ & $25 \%$ Pineapple peel $+75 \%$ Papaya peel & $3.69\left(28.3^{\circ} \mathrm{C}\right)$ & Low \\
\hline $\mathbf{7}$ & $20 \%$ Pineapple peel $+70 \%$ Papaya peel $+10 \% \mathrm{CO}-3$ & $3.66\left(29.9^{\circ} \mathrm{C}\right)$ & Low \\
$\mathbf{8}$ & $30 \%$ Pineapple peel $+50 \%$ Papaya peel $+20 \% \mathrm{CO}-3$ & $3.85\left(28.8^{\circ} \mathrm{C}\right)$ & Moderate \\
\hline $\mathbf{9}$ & & & Moderate \\
\hline $\mathbf{1 0}$ & $70 \%$ Pineapple peel $+20 \%$ Papaya peel $+10 \% \mathrm{CO}-3$ & $3.82\left(29.6^{\circ} \mathrm{C}\right)$ & Moderate
\end{tabular}

The variation in $\mathrm{pH}$ is due to microbial fermentation. During fermentation, bacteria convert plant sugars, water-soluble carbohydrates (WSC), to ferment acids and other compounds ( Muck, 1988, Gowda et al., 2015). Fermentation emits mainly lactic acid in sufficient quantity to reduce $\mathrm{pH}$ quickly. At low $\mathrm{pH}$, further microbial activity and spoilage are prevented due to the acidic 


\section{Somasiri S.C. / Ensiled fruit peels of pineapple (Ananas comosus) and papaya (Carica papaya) as an animal feed}

environment in silage (Saenphoom et al., 2016).

The $\mathrm{pH}$ achieved in well-preserved silage depends on the WSC and dry matter (DM) content of the raw materials used for silage making at the time of ensiling (Saenphoom et al., 2016). But based on findings by Whittenbury et al. (1967), the $\mathrm{pH}$ value of silage is less important when it is evaluated separately because, in good quality silage, the $\mathrm{pH}$ should be dropped quickly so that the ammonium nitrogen and butyric acid amounts are not increased.

The final $\mathrm{pH}$ may be as low as 3.8-4.2 but could exceed 5.0 in heavily wilted silages (Charmley, 2001, Saenphoom et al., 2016). As mentioned in Table 4, the final $\mathrm{pH}$ of most of the silages was in the range 3.8-4.2, which also indicates the quality of silage as moderate. Lemus (2010) mentioned that if the $\mathrm{pH}$ had risen above 4.7, it could be concluded that it was a consequence of undesirable microbial activity. None of the silages had a $\mathrm{pH}$ of above 4.7 in the present study.

\section{Proximate Analysis of Raw Materials}

The rate of the fermentation process, the products of fermentation, and the fermentation quality of the end silage depend on the composition of the parent materials at the time of ensiling. The proximate analysis of fruit peels is given in Table 5. Significantly higher DM content was observed in papaya peels, but CF content was significantly higher in pineapple peels.

Table 5: Proximate analysis of fruit peels (pineapple and papaya)

\begin{tabular}{l|lllll} 
Peel & DM (\%) & CP (\%) & CF (\%) & NDF (\%) & ADF (\%) \\
\hline Pineapple & $16.89^{\mathrm{b}} \pm 0.08$ & $6.51^{\mathrm{b}} \pm 0.01$ & $72.83^{\mathrm{a}} \pm 0.02$ & $25.01^{\mathrm{a}} \pm 0.09$ & $18.88^{\mathrm{a}} \pm 0.01$ \\
Papaya & $18.91^{\mathrm{a}} \pm 0.02$ & $13.86^{\mathrm{a}} \pm 0.1$ & $49.70^{\mathrm{b}} \pm 0.08$ & $13.04^{\mathrm{b}} \pm 0.05$ & $18.61^{\mathrm{b}} \pm 0.02$
\end{tabular}

Data are presented as mean $\pm \mathrm{SE}$

Means with different superscripts within a column are significantly different $(p<0.05)$

DM: dry matter, CP: crude protein, CF: crude fibre, NDF: neutral detergent fibre, ADF: acid detergent fibre

\section{Proximate Analysis of Silage Samples}

Dry matter (DM) content in silage samples: Jais and Rashid (2017) have mentioned that determination of the DM content in silage gives an idea about the amount of particular feed to be fed in order to provide a set of nutrients to the ruminants. In addition, they also have said that the increasing or decreasing in feed DM content could result in over-under-feeding of nutrients. Therefore, DM is an important determinant of intake and preservation of animal feed.

According to the findings by Aboulfotoh (2019), DM content in quality silages ranges from $12 \%$ to $40 \%$, and low values can result in low $\mathrm{pH}$ and poor intake, while higher values cause reduced aerobic stability.

According to Table 6, there was a significant difference in DM contents among treatments $(p<0.05)$. The silage from T8 had the highest $(p<0.05) \mathrm{DM}$ content, and the silage from T2 and T4 had the lowest $(p<0.05)$. DM contents of T3 and T5 were not significantly different but lower $(p<0.05)$ than T8. Likely, DM contents in T7 and T10 were not significantly different from each other but lower $(p<0.05)$ than T3, T5, and T8. Also, DM content in T1, T6, and T9 were not significantly different. The silages having CO-3 had higher DM contents (treatments T7, T8, T9, and T10). As Muck (1988) stated, there is a significant effect on the process and the extent of fermentation that occurs in silage which determines the DM level of raw materials entering the silo. Therefore, the high DM content in 
CO-3 (Table 5) at the time of ensiling may have increased the DM content in T8. DM contents in T2 and T4 are below the recommended values (Aboulfotoh, 2019).

Crude protein $(C P)$ content in silage samples: Protein requirements for livestock usually are expressed as crude protein (Buxton, 1996). According to Table 6, the highest $(p<0.05) \mathrm{CP}$ content was reported in T3, which included $100 \%$ CO-3 grass, and the lowest $(p<0.05) \mathrm{CP}$ contents were in T4 and T5. According to Aboulfotoh (2019), in good quality silage, the CP content should be similar or slightly higher than that of the parent materials. Therefore, T1 is good to make silage. The CP contents of T8, T9, and T10 were closer to the level of ideal quality silage as reported by Lemus et al. (2012); that the CP content in good quality silage ranges from $6 \%$ to $11 \%$. Hence T8, T9, and T10 treatments were also better combinations to make silage. The CP contents of T2, T4, T5, T6, and T7 were very low (below 2\%), and due to which those treatments may not be better combinations to make silage.

The minimum protein content recommended for ruminant diets is $10 \%-12 \%$ (Olorunnisomo and Adesina, 2016). According to Lemus et al. (2012), CP contents of silages and their digestibility tend to vary; high $\mathrm{CP}$ in silages tend to degrade rapidly, leading to poor utilization.

Crude fibre (CF) content in silage samples: According to Table 6, the highest $(p<0.05)$ CF content was reported in T8, and the lowest was reported in T2. According to findings by Gowda et al. (2015), the CF content on DM basis of 20 days ensiled pineapple waste silage was $7.5 \%$. But the CF contents in all the treatments in this study were more than $7.5 \%$. In this study, pineapple and papaya peels, CO-3, and their combinations have been used instead of pineapple waste to prepare silage. So this might be a reason for high CF content in the silages of this study compared to values reported by Gowda et al. (2015).

Neutral detergent fibre (NDF) content in silage samples: NDF can be used as an indicator of feed intake because it represents the total insoluble fibre matrix (Soest and Wine 1967). It is a good estimation of total structural or cell wall contents (cellulose, hemicellulose, and lignin). NDF is important because it estimates the fraction of feed that must be degraded before it can be metabolized by the animal (Saenphoom et al., 2016). According to findings by Gowda et al. (2015), NDF was $56.04 \%$ in 20 days ensiled pineapple waste silage. The Neutral Detergent Fibre (NDF) content (on DM basis) of treatments (Table 6) varied from $18.72 \%$ to $44 \%$. As mentioned in Table 6 , the highest $(p<0.05) \mathrm{NDF}$ content was in T9, and the lowest $(p<0.05) \mathrm{NDF}$ content was in T2 $(18.72 \pm 0.76 \%)$.

Acid detergent fibre (ADF) content in silage samples: ADF is an extract obtained with a detergent solution acidified with sulfuric acid, which results in insoluble residue like NDF, but does not include all cell wall constituents because hemicellulose is soluble in the acid detergent solution (Romelle et al., 2016). In short, ADF is a measure of cellulose and lignin. And lignin reduces cell wall digestibility. The highest $(p<0.05)$ ADF contents were from T3, T8, and T10, and the lowest significant ADF contents were from T5 and T6. The ADF contents in the present study were more than the value reported by Gowda et al. (2015). Low ADF and NDF contents are usually desired for animal feed since these materials complicate digestion and consequently decrease the quality (Sruamsiri and Silman 2009). According to Bureenok et al. (2012), the recommended NDF content of good quality silage ranges from $32 \%$ to $72 \%$ on a DM basis, and ADF content of good quality silage ranges from $25 \%$ to $47 \%$ on a DM basis. Considering that, it can be concluded that the NDF and ADF contents of all the combinations of silages were in the range of good quality silage. 
Somasiri S.C. / Ensiled fruit peels of pineapple (Ananas comosus) and papaya (Carica papaya) as an animal feed

Table 6 Proximate composition of silage samples from each treatment on a dry matter basis

\begin{tabular}{|c|c|c|c|c|c|c|c|c|c|c|}
\hline Treatment & DM(\%) & СР(\%) & $\mathrm{CF}(\%)$ & $\mathrm{EE}(\%)$ & $\operatorname{Ash}(\%)$ & NFE(\%) & NDF(\%) & ADF(\%) & TDN(\%) & $\begin{array}{l}\text { ME } \\
\text { (Mcal/kg) }\end{array}$ \\
\hline T1 & $12.28^{\mathrm{d}} \pm 0.33$ & $6.96^{\mathrm{b}} \pm 0.01$ & $21.90^{\mathrm{e}} \pm 0.12$ & $3.56^{\mathrm{a}} \pm 0.41$ & $8.62^{\mathrm{d}} \pm 0.11$ & $58.94^{\mathrm{c}} \pm 0.42$ & $38.95^{\mathrm{c}} \pm 0.28$ & $24.89^{\mathrm{e}} \pm 0.03$ & $61.45^{\mathrm{c}} \pm 0.24$ & $2.22^{\mathrm{c}} \pm 0.01$ \\
\hline T3 & $15.27^{b} \pm 0.31$ & $14.02^{\mathrm{a}} \pm 0.39$ & $29.52^{\mathrm{c}} \pm 0.49$ & & $8.46^{\mathrm{d}} \pm 0.14$ & & & & & $2.38^{\mathrm{a}} \pm 0.02$ \\
\hline T4 & $11.59^{\mathrm{e}} \pm 0.72$ & $0.32^{g} \pm 0.02$ & $29.98^{c} \pm 0.12$ & $1.39^{\mathrm{d}} \pm 0.00$ & $9.92^{\mathrm{c}} \pm 0.00$ & $58.37^{\mathrm{c}} \pm 0.10$ & $36.01^{\mathrm{e}} \pm 0.03$ & $25.73^{\mathrm{d}} \pm 0.11$ & $53.97^{\mathrm{e}} \pm 0.01$ & $1.95^{\mathrm{e}} \pm 0.00$ \\
\hline T6 & $12.49^{\mathrm{d}} \pm 0.10$ & $1.72^{\mathrm{e}} \pm 0.02$ & $20.31^{\mathrm{f}} \pm 0.07$ & $1.37^{\mathrm{d}} \pm 0.05$ & $11.78^{b} \pm 0.06$ & $64.80^{\mathrm{b}} \pm 0.06$ & $22.38^{\mathrm{h}} \pm 0.06$ & $23.77^{f} \pm 0.03$ & $50.38^{\mathrm{g}} \pm 0.18$ & $1.82^{\mathrm{g}} \pm 0.01$ \\
\hline T7 & $14.49^{c} \pm 0.92$ & $4.97^{\mathrm{d}} \pm 0.03$ & $25.31^{\mathrm{d}} \pm 0.44$ & $1.46^{\mathrm{d}} \pm 0.02$ & $13.38^{\mathrm{a}} \pm 0.04$ & $54.86^{\mathrm{d}} \pm 0.33$ & $33.64^{\mathrm{f}} \pm 0.38$ & $29.73^{c} \pm 0.13$ & $49.86^{\mathrm{g}} \pm 0.07$ & $1.80^{\mathrm{g}} \pm 0.00$ \\
\hline T8 & $18.21^{\mathrm{a}} \pm 0.05$ & $6.34^{\mathrm{c}} \pm 0.01$ & $31.36^{\mathrm{a}} \pm 0.12$ & $2.04^{\mathrm{c}} \pm 0.01$ & $13.56^{\mathrm{a}} \pm 0.01$ & $46.68 \pm 0.13$ & $37.43^{\mathrm{d}} \pm 0.55$ & $32.61^{\mathrm{a}} \pm 0.03$ & $51.53^{\mathrm{f}} \pm 0.01$ & $1.86^{\mathrm{f}} \pm 0.00$ \\
\hline T9 & $12.86^{\mathrm{d}} \pm 0.09$ & $6.15^{\mathrm{c}} \pm 0.04$ & $30.29^{b} \pm 0.06$ & $1.96^{c} \pm 0.02$ & $9.86^{\mathrm{c}} \pm 0.02$ & $51.72^{\mathrm{e}} \pm 0.05$ & $44.00^{\mathrm{a}} \pm 0.02$ & $30.40^{b} \pm 0.17$ & $57.88^{\mathrm{d}} \pm 0.03$ & $2.09^{\mathrm{d}} \pm 0.00$ \\
\hline
\end{tabular}

Data are presented as mean $\pm \mathrm{SE}$

Means with different superscripts within a column are significantly different $(p<0.05)$

DM: dry matter, CP: crude protein, CF: crude fibre, EE: ether extract, NFE: nitrogen-free extract

NDF: neutral detergent fibre, ADF: acid detergent fibre, TDN: total digestible nutrients, ME:

metabolizable energy

Ether extract of silage samples: As stated in Table 6, the highest $(p<0.05)$ EE was from T1, T3, and T10, and the lowest $(p<0.05)$ EE was observed in T6 and T7. Palmquist (1994) reported that the maximum recommended EE content for a diet based on compound feed is $5 \%$. Therefore, it can be concluded that the EE contents in the silages are within the recommended range.

Ash content and nitrogen-free extract (NFE) of silage samples: The highest $(p<0.05)$ ash contents were obtained from T5, T7, and T8, and the lowest $(p<0.05)$ ash content was observed from T2. The Nitrogen Free Extract (NFE) content (Table 6) was highest $(p<0.05)$ in T2 and lowest $(p<0.05)$ in T3.

\section{Total Digestible Nutrients (TDN) and Metabolizable Energy (ME) Contents in Silage Samples}

Total digestible nutrients are a general measure of the nutritive value of a feed, and in vitro, TDN is tested or calculated outside the animal. The highest $(p<0.05)$ TDN content was observed in T3 and the lowest $(p<0.05)$ in T5. The TDN contents in T9 and T2 were not significantly different. Also, TDN contents in T6 and T7 were not significantly different $(p>0.05)$.

Metabolizable energy (ME) is the energy left after accounting for energy in faeces, urine, and gases. The ME content of individual feeds is rarely measured. Measuring the amounts of energy lost in gaseous form and in the urine is more difficult. Thus, conversion formulas are often used when ME content is needed. The highest $(p<0.05) \mathrm{ME}$ content was observed in T3 and the lowest $(p<0.05)$ in T5. The ME contents in T9 and T2 were not significantly different $(p>0.05)$. Also, ME contents in T6 and $\mathrm{T} 7$ were not significantly different. 
Somasiri S.C. / Ensiled fruit peels of pineapple (Ananas comosus) and papaya (Carica papaya) as an animal feed

Ammonium Nitrogen Content in Silage Samples

Table 7 Quality of silage based on Ammonium- $N$

\begin{tabular}{c|c} 
Amount & Quality \\
\hline Very low & High quality \\
Low & Good quality \\
\hline Moderate & Medium quality \\
High & Low quality \\
\hline Very high & Very low quality
\end{tabular}

Source: Fernando and Nanthakumaran (2018).

Ammonium Nitrogen in silage is a principal product of Clostridial fermentation of amino acids (Charmley, 2001; Ohshima and McDonald, 1978). Ammonium N in silage has long been associated with reduced silage intake (Charmley, 2001). If the silage fermentation is poor, intake will be depressed, and the animal's response to silage feeding will be poor (Saenphoom et al., 2016). Ammonium - $\mathrm{N}$ is the best simple test of silage fermentation quality and should be $10 \leq$ total $\mathrm{N} \%$, according to findings by Charmley (2001). Therefore, as Ammonium Nitrogen was not detected in any of the silages, the silages were of good quality.

\section{Conclusion}

The treatments T1 (100\% pineapple peels), T8 (30\% pineapple peels $+50 \%$ papaya peels $+20 \% \mathrm{CO}-3$ grass), T9 (70\% pineapple peels $+20 \%$ papaya peels $+10 \%$ CO-3 grass), and $\mathrm{T} 10$ (50\% pineapple peels $+30 \%$ papaya peels $+20 \%$ CO-3 grass) had the moderate quality $\mathrm{pH}$ value, good physical characteristics, and recommended nutrient compositions. Thus, these treatment silages can be selected for further studies using in-vivo animal models.

\section{Acknowledgement}

The authors acknowledge the Lanka Canneries PVT Ltd for providing fruit peels and Head and the staff of the Departments of Animal \& Food Sciences and Agricultural Engineering \& Soil Science, Faculty of Agriculture, Rajarata University of Sri Lanka for providing the required facilities for the research to be completed successfully.

\section{References}

Aboulfotoh, G.E. (2019). Nutritional evaluation of silage from some annual forages, (February).

AOAC (2005). Official methods of analysis. Association of official analytical chemist (18 $8^{\text {th }}$ ed.). Washington DC, USA.

Bureenok, S., Yuangklang, C., Vasupen, K., Schonewille, J.T. and Kawamoto, Y., 2012. The effects of additives in napier grass silages on chemical composition, feed intake, nutrient digestibility and rumen fermentation. Asian-Australasian journal of animal sciences, 25(9), p.1248.

Buxton, D.R., 1996. Quality-related characteristics of forages as influenced by plant environment and agronomic factors. Animal feed science and technology, 59(1-3), pp.37-49.

Charmley, E., 2001. Towards improved silage quality-A review. Canadian Journal of Animal Science, 81(2), pp.157-168. 


\section{Somasiri S.C. / Ensiled fruit peels of pineapple (Ananas comosus) and papaya (Carica papaya) as an animal feed}

Devendra, C., 1998. Non-conventional feed resources and fibrous agricultural residues: strategies for expanded utilization; proceedings of a consultation held in Hisar, India, 21-29 Mar. 1998.

Devendra, C., and Sevilla, C.C., 2002. Availability and use of feed resources in crop- animal systems in Asia. Agricultural systems, 71 (1-2), pp. 59-73.

Epasinghe, T.M., Jayawardena, V.P. and Premalal, G.G.C., 2012. Comparison of growth, yield and nutritive value of maize, multi-cut fodder sorghum and hybrid Napier (var. Co3) grown in wet zone of Sri Lanka. Proceedings of 22nd Annual Students Research Session. Department of Animal Science, University of Peradeniya, Sri Lanka, p.23.

Feranando, K.S.D. and Nanthakumaran, A., 2018. Crop residues with fodder trees to produce good quality silage.

Fonnesbeck, P.V., Wardeh, M.F. and Harris, L.E., 1984. Mathematical models for estimating energy and protein utilization of feedstuffs. Bulletin/Utah Agricultural College Experiment Station (USA).

Gowda, N.K.S., Vallesha, N.C., Awachat, V.B., Anandan, S., Pal, D.T. and Prasad, C.S., 2015. Study on evaluation of silage from pineapple (Ananas comosus) fruit residue as livestock feed. Tropical animal health and production, 47(3), pp.557-561.

Ibrahim, M.N.M., 1988. Feeding tables for ruminants in Sri Lanka. Animal Feed Advisory Committee Veterinary Research Institute.

Jais, M.A. and Rashid, H.N.M., 2017. Alternative livestock feed from fermented banana peel. Journal of Academia, 5(1), pp.1-8

Kaiser, A.G., Piltz, J.W., Burns, H.M. and Griffiths, N.W., 2004. Successful silage. Dairy Australia NSW Department of Primary Industries, $468 p$.

Kasapidou, E., Sossidou, E., and Mitlianga, P., 2015. Fruit and vegetable co-products as functional feed ingredients in farm animal nutrition for improved product quality. Agriculture, 5(4), pp.1020-1034.

Kung Jr, L., Shaver, R.D., Grant, R.J. and Schmidt, R.J., 2018. Silage review: Interpretation of chemical, microbial, and organoleptic components of silages. Journal of dairy Science, 101(5), pp.4020-4033.

Lemus, R., 2010. Understanding silage making process and utilization. Cooperative Extension Service, Mississippi State University: Starkville, MS, USA, 3.

Lemus, C., Bonilla, J., Plasencia, A. and Ly, J., 2012. Chemical characteristics of silages of mango (Mangifera indica L.) by-products for animal feeding. Cuban Journal of Agricultural Science, 46(4).

Livestock Statistical Bulletin, 2017., Department of Animal Production and Health, Peradeniya, Sri Lanka.

Markus, D.K., McKinnon, J.P. and Buccafuri, A.F., 1985. Automated analysis of nitrite, nitrate, and ammonium nitrogen in soils. Soil Science Society of America Journal, 49(5), pp. 1208-1215.

MCDonald, P., 1981. The biochemistry of silage. John Wiley\&. Sons. Chichester, New York Brisbane Toronto.

Muck, R.E., 1987. Dry matter level effects on alfalfa silage quality I. Nitrogen transformations. Transactions of the ASAE, 30(1), pp.7-0014.

Muck, R.E., 1988. Factors influencing silage quality and their implications for management. Journal of Dairy Science, 71(11), pp.2992-3002. 


\section{Somasiri S.C. / Ensiled fruit peels of pineapple (Ananas comosus) and papaya (Carica papaya) as an animal feed}

Ohshima M, McDonald P., 1978. A review of the changes in nitrogenous compounds of herbage during ensilage. Journal of the Science of Food and Agriculture,29(6), pp.497-505.

Olorunnisomo, O.A. and Adesina, M.A., 2014. Silage Characteristics, Nutritive Value and Preference of Zebu Cows for Moringa Leaf Ensiled with Different Levels of Cassava Peel. Journal of Applied Agricultural Research, 6(1), pp.191-196.

Palmquist, D.L., 1994. The role of dietary fats in efficiency of ruminants. The Journal of nutrition, 124(suppl_8),pp.1377S-1382S.

Randa, S.Y., Lekitoo, M., Iyani, D.A. and Pattiselanno, F., 2018. Nutritive Value and the Quality of Ensiled Napier Grass (Pennisetum purpureum Schum.) and Banana (Musa acuminata) Peelings. Animal Production, 19(2), pp. 101-110.

Rani, D.S., \& Nand, K.,2004. Ensilage of pineapple processing waste for methane generation. Waste management, 24(5), 523-528.

Romelle, F.D., Rani, A. and Manohar, R.S., 2016. Chemical composition of some selected fruit peels. European Journal of Food Science and Technology, 4(4), pp.12-21.

Saenphoom, P., Chimtong, S. and Chaokaur,A. (2016). Nutritive Value, Digestibility and Gas Production of Fermented Sugar Palm Peel with Pineapple Peel, 10(1): 32-37pp.

Soest, P.V. and Wine, R.H., 1967. Use of detergents in the analysis of fibrous feeds. IV. Determination of plant cell-wall constituents. Journal of the Association of Official Analytical Chemists, 50(1), pp.50-55.

Selwet, M.A.R.E.K., 2006. Effect of organic acids and bacterial- enzymatic preparations on the number of fungal populations and silage aerobic stability. Bulletin-Veterinary Institute in Pulawy, 50(2), p.215.

Selwet, M., 2008. Effect of organic acids on numbers of yeasts and mould fungi and aerobic stability in the silage of corn. Polish Journal of Veterinary Sciences, 11(2): 119.

Sruamsiri, S. and Silman, P., 2009. Nutritive value and nutrient digestibility of ensiled mango byproducts. Maejo International Journal of Science and Technology, 3(3), pp.371-378.

Wadhwa, M., and Bakshi, M.P.S., 2013. Utilization of fruit and vegetable wastes as livestock feed and as substrates for generation of other value-added products. Rap Publication, 4, pp. 1-67.

Weeresinghe, W.M.P.B., 2019., Livestock Feeds and Feeding Practices in Sri Lanka. Livestock Feeds and Feeding Practices in South Asia, p.181.

Whittenbury, R., McDonald, P. and Bryan-Jones, D.G., 1967. A short review of some biochemical and microbiological aspects of ensilage. Journal of the Science of Food and Agriculture, 18(10), pp.441-444.

Wickramasuriya S.S., Yi, Y.J., Yoo, J., Kang, N.K. and Heo, J.M., 2015. A review of canola meal as an alternative feed ingredient for ducks. Journal of animal science and technology, 57(1), 